\title{
STUDY OF THE EFFECT OF CRUDE EXTRACTS OF Sonchus oleraceus ON CANCER CELL GROWTH (In vivo)
}

\author{
**Zeinab R.Zgheir *Nahi Y. Yaseen ** Talib A. Makkawi \\ * Iraqi Centre for Cancer and Medical Genetics Research/ Mustansiriyah University \\ ** college of vet. Med. Baghdad Uni.
}

Accepted date 11/5/2010

\section{Summary}

The in vivo study was designed to evaluate the anticancer effects of these three types of the extracts on the AM-3 (Murine mammary adenocarcinoma). The $\mathrm{LD}_{50}$ was $(5 \mathrm{~g} / \mathrm{kg}, 6 \mathrm{~g} / \mathrm{kg}$ and 8 $\mathrm{g} / \mathrm{kg}$ ) for ethanolic, hot aqueous and cold aqueous extracts respectively. The therapeutic doses of extracts were daily injected subcutaneously for two weeks, three weeks and four weeks. The histopathological study revealed pathological changes in some organs; the group that treated with ethanolic extract showed sever deposition of amyloid in some organs like spleen. The blood vessel filled with inflammatory cells as neutrophiles and cells infiltration in the lung tissue. Hot and cold aqueous extracts showed inflammatory mononuclear cells infiltration in the kidney and lung, section with necrosis in most of the cancer cells in the lung tissue; with few necrotic changes in the normal tissue were noticed after one month of treatment by hot and cold aqueous extracts.

\section{دراسة تأثير المستخلصات الخام لتبات المرّير Sonchus oleraceus على نمو الخلايا السرطانية (داخل الجسم)}

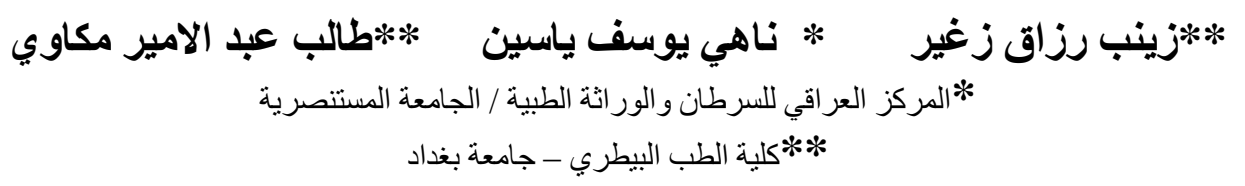

الخلاصة

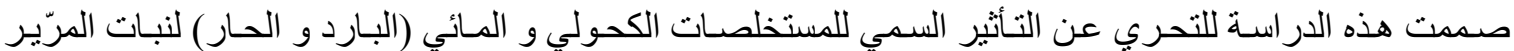
Sonchus oleraceus

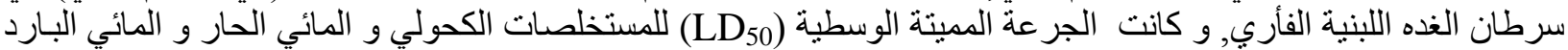

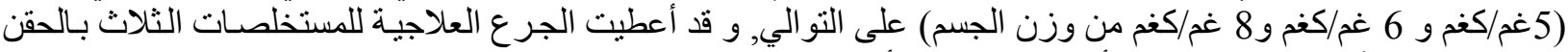

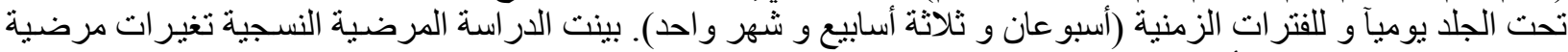

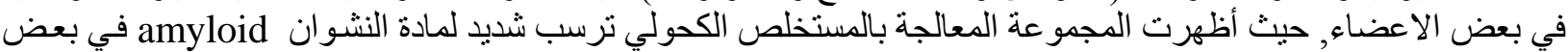

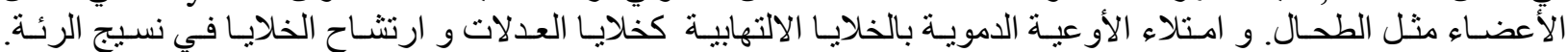

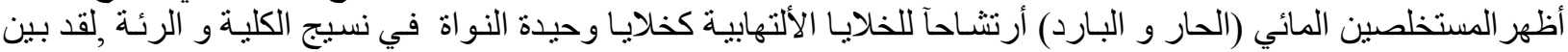

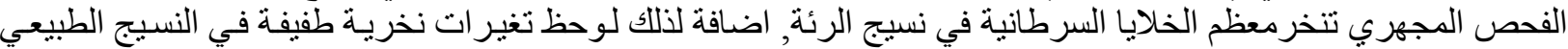
بعد مرور شهر من العلاج بالمستخلصين المائي ( الباردو و الحار).

\section{Introduction}

Recent developments of modern techniques of targeted tumour cell elimination (1) include immunotherapy, which also called biological therapy, that uses the body's own immune system to fight cancer (2), and genetherapy, as a new trials to treat cancer (1'). However, there is a continuing need for development of new anticancer drugs, drug combinations and chemotherapy 


\section{Iraqi Journal of Veterinary Medicine Vol. 34, No. 1, 2010}

strategies, by methodical and scientific exploration of enormous pool of synthetic, biological and natural products (3).

Recently introduced drugs have been obtained from wild plants such as taxol from the Pacific yew, Taxus brevifolia, Catharanthus roseus or Vinca rosea (Periwinkle) (4). Another prominent molecule includes Podophyllotoxin; as synthetic modification, known to be effective for small cell cancers. Other important molecules include Vincristine, Vinblastine, Colchicine, Ellipticine and Lepachol along with Flavopiridol, a pyridoindole alkaloid from leaves of Ochrosia species and many more (2).

Sonchus oleraceus (Common sowthistle) is quite common in Iraq; this plant is a winter to spring annual adaptable and found in full or partial sun, moist to slightly dry sites, and soil that is fertile, so it is a weed. The seeds are used for medicine and young leaves are edible. It was suggested that the antioxidant activity in plants depend on environment factors such as growing season (5) and location (6). However, detailed information on antioxidative activities of the $S$. oleraceus was not sufficiently available. The antioxidant activities of $S$. oleraceus , including the free radical scavenging activity, nitrite scavenging activity, total phenolic content, and flavonoid content. S. oleraceus might be a source of food and natural antioxidants (7). Extracts of Sonchus oleraceus aim to study the effect of extracts of Sonchus oleraceus on the growth of transplanting tumor in mice in vivo.

Extraction of test plant:

\section{Metraials and methods:}

- Preparation of ethanolic, hot and cold aqueous of Sonchus oleraceus:

According to (8), ethanolic and cold aqueous extract were prepared.

a) Ethanolic extract

1- Ethanolic extract of plant was weighting $50 \mathrm{~g}$ of powder and dissolved in $250 \mathrm{ml}$ of $70 \%$ ethanolic alcohol extract in Erlyn Myer flask and stirred on magnetic stirrer for 72 hours at room temperature.

2 -The sediments were filtered by gauze and then by filter pape. The mixture was filtered by using filter paper (Wattman No.1).

3- The supernatant was evaporated to dryness $\left(45^{\circ} \mathrm{C}\right)$ under reduced pressure in a rotary evaporator.

4- The weight of crude extract resulted from that amount of powdered plant was measured.

5- The crude extract then was kept at $-20^{\circ} \mathrm{C}$ until the time of use.

b) Cold aqueous extract

The cold aqueous extract of Sonchus oleraceus was prepared in the same manner as that of the ethanolic extract except using of distilled water instead of $70 \%$ ethanolic alcohol, and the aqueous extract left at room temperature to remove any water stay.

c) Hot aqueous extract

This type of extract was prepared according to (9). After weighting of $50 \mathrm{~g}$ of powder and dissolved in $250 \mathrm{ml}$ of distilled water and stirred on magnetic stirrer for 5-8 hours at 90 degree.C. The resulting dark brown extract then it has cooled to room temperature .The pooled extract was evaporated to dryness $\left(45^{\circ} \mathrm{C}\right)$ under reduced pressure in rotary evaporator, also the crude extract was kept at $-18{ }^{\circ} \mathrm{C}$. For following experiments, $1 \mathrm{~g}$ of powdered plant extract was dissolved into $10 \mathrm{ml}$ PBS (as solvent), the suspension then filtered and sterilized by using $0.4 \mu \mathrm{m}$ sterile Millipore filter and kept in deep freeze $\left(-20^{\circ} \mathrm{C}\right)$ until use.

- Detection of active compounds

1- Detection of Tannins

Ten grams of the plant powder was mixed with $50 \mathrm{ml}$ of distilled water using a magnetic stirrer, the mixture was left in a boiling water bath for few minutes, then filter it and the supernatant solution was treated with the two detection methods of tannins as the following indicator: 


\section{Iraqi Journal of Veterinary Medicine Vol. 34, No. 1, 2010}

Aqueous ferric chloride $1 \%$ solution, the development of the greenish-blue precipitate was an indication of the presence of tannins (8).

2- Detection of Saponins

A) Foam tests for aqueous: Thick foam presence as an indication.

B) Aqueous mercury chloride 1\%: Five $\mathrm{ml}$ of plant extract was added to (1-4 ml) of indicator the presence of white precipitate was an indication of saponin (10).

3-Detection of Flavonoids

A) Ten gm from powder explants were dissolved in ethanol $95 \%$ then filter it.

B) Ten $\mathrm{ml}$ of ethanol $50 \%$ were added to $10 \mathrm{ml}$ of aqueous $\mathrm{KOH} 50 \%$ mix A with $\mathrm{B}$ the appearance of yellow color evidence of flavonoids (8).

4- Detection of Glycosides

A) Equal amounts of the water extract was mixed with Fehling's reagent in a test tube, then boiled in a water bath for $10 \mathrm{~min}$ the formation of red precipitate indicated the presence of glycosides.

B) One $\mathrm{ml}$ of Pandect's reagent was added about $5 \mathrm{ml}$ of plant extract; the formation of red precipitate indicated the presence of glycosides (11).

5-Detection of Terpenes

This indicator used to detect for the terpenes commonly about $1 \mathrm{ml}$ of chloride antimon chloroform $20 \%$ was added to $5 \mathrm{ml}$ of plant extract, the appearance of white precipitate indicated the presence of terpenes (8).

6-Detection of Alkaloids

Ten gm of plant powder was boiled with $50 \mathrm{ml}$ of distal water (with $4 \% \mathrm{HCL}$ ) then filtered and left to be cool. Half $\mathrm{ml}$ of this solution was added to $0.5 \mathrm{ml}$ of the following indicator:-

A) Wagner's Reagent: after added the reagent, the appearance of brown precipitate indicated the presence of alkaloid (12).

B) Mayer's Reagent: when adding this reagent, the appearance of white precipitate indicated the presence of alkaloid (12).

C) Dragendorff s Reagent: This reagent cause, the appearance of orange precipitate indicated the presence of alkaloids (13).

D) Tannic Reagent: one gram of tannic acid was added to $100 \mathrm{ml}$ of distal water, and when used we added $1 \mathrm{ml}$ of reagent to $1-2 \mathrm{ml}$ of aqueous or alcoholic extract, the appearance of white precipitate indicated the presence of alkaloids (13).

7- Detection of General Phenols

Equal quantity of aqueous ferric chloride $1 \%$ was mixed with potassium iron cyanide $1 \%$. And equal quantity of reagent and aqueous or Alcoholic plant extract were used. The appearance of blue-green colour indicated the presence of phenols (8).

- Median lethal dose (LD50):

- Experimental animals

Females thirty number (6-8 week-old, 20-30g) mice were obtained from the animal house of Iraqi Center for Cancer and Medical Genetics Researches, were used to determine the median lethal dose (LD50) subcutaneously of ethanolic, hot and cold aqueous extract of Sonchus oleraceus.The animals were kept in well air-condition rooms given pellets of balanced specially prepared animal feed and water ad libidum.

- Determination of LD50

The determination of median lethal dose (LD50) was down according to (14) (up and down) method. Animals that used in this study were ( 45 adult mice) and divided into three groups (ethanolic, cold and hot aqueous) extracts, each one contain 15 mice. The ranges of single subcutaneous doses which were used in the determination of LD50 of three extracts were (4000$10000 \mathrm{mg} / \mathrm{Kg}$ of B.W). Mortality was observed during 24hours post treatment period and recorded as $\mathrm{O}$ if the animal live and then increased the treated dose. While $\mathrm{X}$ recorded for the death of animal and then decreased the dose according for the result of the animal, the LD50 of 


\section{Iraqi Journal of Veterinary Medicine Vol. 34, No. 1, 2010}

the group that administered by ethanolic extract showed at (5000 $\mathrm{mg} / \mathrm{Kg}$ of B.W), and the group of cold aqueous extract at $(8000 \mathrm{mg} / \mathrm{Kg}$ of B.W), while hot aqueous extract group at (6000 mg / Kg of B.W). The tabular value can get and the LD50 was determined according to the formula employed by.

$\mathrm{LD} 50=\mathrm{X} f+\mathrm{Kd}$

$\mathrm{X} f=$ the last dose administered.

$\mathrm{K}=$ the tabular value,

$\mathrm{d}=$ the interval between doses.

- Tumour growth inhibition (in vivo study)

- Transplantation of tumour cells in mice

The tumor (mammary adenocarcinoma) bearing female mouse (AM3) was supplied by ICCMGR. This mouse was used as source of tumour which transplanted in other mice. The following steps were followed to perform the transplantation process (15).

The tumour mass region was well disinfected with $70 \%$ ethyl alcohol. By using $10 \mathrm{ml}$ disposable syringes, the contents of tumour mass tissue were withdrawn into sterile flask and suspended into $50 \mathrm{ml}$ of sterile PBS. The solid contents were allowed to settle down while the supernatant discarded. The sediments washed 2-3 times with sterile PBS. Each adult female mice (6-8 weeks) was given $0.2 \mathrm{ml}$ of tumour cell suspension through insertion of a needle (gauge no.18) subcutaneously from thigh region toward the houlder region, the mice become ready to be used in the therapeutic experiment. (Approximately 14 days following inoculation). Tumour growth and tumour measurements were observed and recorded by using vernia calibre (16).

Tumour volume $\left(\mathrm{mm}^{3}\right)=\mathrm{aXb}^{2} / 2$

$\mathrm{a}=$ length of tumour mass $(\mathrm{mm})$

$\mathrm{b}=$ width of tumour mass $(\mathrm{mm})$

The relative tumour volume (RTV) is calculated from the following equation:

$\mathrm{RTV}=($ Tumor volume at day $\mathrm{X} /$ Tumor volume at day $\mathrm{O})$

The tumor growth inhibition GI \% can be calculated from the following equation:

$\mathrm{TGI}=[(\mathrm{RTV}$ of treated $-\mathrm{RTV}$ of control $) / \mathrm{RTV}$ of control $] \times 100$

- Therapeutic Experiment:

The inoculated mice were randomized into three groups of (ethanolic,cold and hot aqueous) extracts each one contain of 15 adults female mice were divded into three periods of treatment for (two weeks, three weeks and one month) each one period had five animals and three control groups administered PBS each one contain five animals for each period . The therapeutic doses was down according to (14) $(500 \mathrm{mg} / \mathrm{Kg}$ ) of ethanolic extract, $(800 \mathrm{mg} / \mathrm{Kg}$ ) of cold aqueous extract, $(600 \mathrm{mg} / \mathrm{Kg}$ ) of hot aqueous extract, the administration was done subcutaneously were injected daily. The development of tumour was measured twice a week.

- Specimens Collection:

After the periods of treatment, for the all groups, were finished the animals were killed by anesthesia to obtain the following:

Each mouse fixed anatomical container and washing by alcohol (70\%) and then the organs were obtained, then fixed in buffer formalin for study the histopathological changes to detect the metastasis of cancer cell to bone marrow, bone marrow was obtained from the femur to measure the (MI) of cells.

- Extraction:

\section{Results}

The dried leaves of ethanolic, cold aqueous and hot aqueous extracts of Sonchus oleraceus as in the table (1) gave a dark brown sticky product, which became powder upon drying. Hot aqueous extract gave darker brown colour than ethanolic and cold aqueous extracts. 


\section{Iraqi Journal of Veterinary Medicine Vol. 34, No. 1, 2010}

Table (1): The percentage of crude extraction of Sonchus oleraceus

\begin{tabular}{|c|c|c|c|}
\hline Type of extract & \begin{tabular}{|l} 
Weight of plant par \\
(gm)
\end{tabular} & $\begin{array}{l}\text { Weight of extract } \\
\text { gm }\end{array}$ & $\begin{array}{l}\text { Percentage } \\
\text { extraction \% }\end{array}$ \\
\hline Ethanolic extract & 40 & 3.48 & 8.7 \\
\hline Cold aqueous ex. & 40 & 3.24 & 8.1 \\
\hline Hot aqueous ex. & 40 & 4.88 & 12.2 \\
\hline
\end{tabular}

- General chemical detection of active compounds:

Chemicals detection indicated the presence of glycosides in the three types of extractions of Sonchus oleraceus as seen in table (2), flavonoid and tannins presence in ethanolic extract. Tannins in cold aqueous extract are present but not in hot aqueous extract and from this table the ethanolic extract have more activity from the aqueous extract.

Table (2): The results of some active compounds detection for crude extracts of sonchus oleraceus

\begin{tabular}{|c|c|c|c|}
\hline $\begin{array}{l}\text { Chemical } \\
\text { compounds }\end{array}$ & Ethanolic extract & Cold aqueous extract & Hot aqueous extract \\
\hline Tannins & + & + & - \\
\hline Saponins & - & - & - \\
\hline Flavonoids & + & - & - \\
\hline Glycosides & + & + & + \\
\hline Terpenes & - & - & - \\
\hline Alkaloids & - & - & - \\
\hline Phenols & - & - & - \\
\hline
\end{tabular}

- Treatment of tumour by using plant extracts (in vivo study):

-Tumour Growth Inhibition (T.G.I) \%:

The percentage of tumour growth inhibition in different animals groups, the results showed that the best inhibitory effect on T.G.I was obtained from the hot aqueous extract for two weeks, while the ethanolic extract showed the best inhibitory effect for three weeks and one month.

In table (3) the results refer that all groups have significant $(\mathrm{P}<0.05)$ inhibition percentage at the period of two weeks. The hot aqueous extract gradually increase the tumour growth inhibition depends to the time, while the ethanolic extract showed increase in TGI at the periods of sixth (17) and fifteenth days (18). Cold aqueous extract also revealed increase in TGI at the periods ninth (19) and the twelve day (7). The ethanolic extract had not inhibitory effect during the twelve day (20) also cold aqueous extract had not inhibitory effect during the sixth day (10).

Table (4) exhibits tumour growth inhibition percentage (T.G.I) \% of treated animal groups that treated with (ethanolic, cold aqueous \& hot aqueous) extracts of Sonchus oleraceus for three weeks. Also all groups had significant $(\mathrm{P}<0.05)$ inhibition percentage and the hot aqueous extract gradually increased the tumour growth inhibition depends to the periods, and the highest inhibition percentage of TGI was (42.3) for the ethanolic extract at the twelve day, while the cold aqueous extract shows no inhibitory effect at the sixth day (2.3). 


\section{Iraqi Journal of Veterinary Medicine Vol. 34, No. 1, 2010}

Table (5) reveales tumour growth inhibition of Sonchus oleraceus extracts for one month. The therapeutic groups had significant inhibition $(\mathrm{P}<0.05)$. The highest inhibition percentage of TGI in the ethanolic extract was 62.6 at the ninth day, and no inhibitory effect at twenty seven and thirty days (5.2 and 1) respectively. Cold and hot aqueous extracts showed no inhibitory effect at the sixth day (0) for both.

Table (3): Mean values of tumour growth inhibition percentage (T.G.I) $\%$ of treated animal groups that treated with (ethanolic, cold aqueous \& hot aqueous) extracts of Sonchus oleraceus for two weeks.

\begin{tabular}{|c|c|c|c|c|c|c|}
\hline \multirow{3}{*}{$\begin{array}{l}\text { Types of } \\
\text { extract }\end{array}$} & \multicolumn{6}{|c|}{ Tumour Growth Inhibition (T.G.I) \% } \\
\hline & \multicolumn{6}{|c|}{ Periods of measurement of (T.G.I)\% } \\
\hline & 3 days & 6 days & 9 days & 12 days & 15 days & $\overline{\mathrm{LSD}}$ \\
\hline $\begin{array}{l}\text { Ethanolic } \\
\text { extract }\end{array}$ & 11 & 26 & 24 & 1 & 9 & $* 3.4$ \\
\hline $\begin{array}{l}\text { Cold } \\
\text { aqueous } \\
\text { extract }\end{array}$ & 17 & 2 & 21 & 38 & 27 & * 3.8 \\
\hline $\begin{array}{l}\text { Hot } \\
\text { aqueous } \\
\text { extract }\end{array}$ & 15 & 15 & 32 & 38 & 39 & $* 4.7$ \\
\hline$\overline{\mathrm{LSD}}$ & $\overline{* 3.9}$ & $* 2.8$ & * 5.4 & $* 4.2$ & * 5.2 & \\
\hline
\end{tabular}

(*) mean significant difference between means comparation with columns groups and in comparation with arrows groups at levels $(\mathrm{P}<0.05)$.

Table (4): Mean values of tumour growth inhibition percentage (T.G.I) $\%$ of treated animal groups that treated with (ethanolic, cold aqueous \& hot aqueous) extracts of Sonchus oleraceus for three week

\begin{tabular}{|c|c|c|c|c|c|c|c|c|}
\hline \multirow{3}{*}{$\begin{array}{l}\text { Types of } \\
\text { extract }\end{array}$} & \multicolumn{8}{|c|}{ 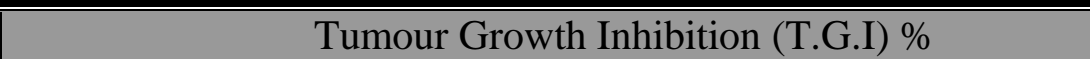 } \\
\hline & \multicolumn{8}{|c|}{ Periods of measurement of (T.G.I)\% } \\
\hline & \begin{tabular}{|l}
3 \\
days
\end{tabular} & $\begin{array}{l}6 \\
\text { days }\end{array}$ & $\begin{array}{l}9 \\
\text { days }\end{array}$ & $\begin{array}{l}12 \\
\text { days }\end{array}$ & $\begin{array}{l}15 \\
\text { days }\end{array}$ & $\begin{array}{l}18 \\
\text { days }\end{array}$ & $\begin{array}{l}21 \\
\text { days }\end{array}$ & LSD \\
\hline $\begin{array}{l}\text { Ethanolic } \\
\text { extract }\end{array}$ & 33 & 25 & 35.5 & 42.3 & 34 & 21.4 & 19.5 & * 3.7 \\
\hline $\begin{array}{l}\text { Cold } \\
\text { aqueous } \\
\text { extract }\end{array}$ & 16 & 2.3 & 29 & 34.4 & 39.7 & 41.3 & 42 & $* 4.8$ \\
\hline $\begin{array}{l}\text { Hot } \\
\text { aqueous } \\
\text { extract }\end{array}$ & 12 & 16.4 & 28.5 & 29 & 30.3 & 37.2 & 36.2 & $* 3.4$ \\
\hline LSD & $* 3.8$ & *3.9 & $* 4.3$ & $* 3.9$ & * 5.7 & $* 5.3$ & $* 4.7$ & \\
\hline
\end{tabular}

mean significant difference between means comparation with columns groups and in comparation with arrows groups at levels $(\mathrm{P}<0.05)$. 


\section{Iraqi Journal of Veterinary Medicine Vol. 34, No. 1, 2010}

Table (5): Mean values of tumour growth inhibition percentage (T.G.I) $\%$ of treated animal groups that treated with (ethanolic, cold aqueous \& hot aqueous) extracts of Sonchus oleraceus for one month.

\begin{tabular}{|l||l||l|l||l|l|l||l|l||l||l||}
\hline \hline & \multicolumn{7}{|c|}{ Tumour Growth Inhibition (T.G.I) \% } \\
$\begin{array}{l}\text { Types } \\
\text { extract }\end{array}$
\end{tabular}

(*) mean significant difference between means comparation with columns groups and in comparation with arrows groups at levels $(\mathrm{P}<0.05)$.

Histopathological Study:

The group which treated with ethanolic extract at the period of two weeks, treatment the spleen showed deposition of diffuse amyloid around the white bulb which leads to deletion of the lymphocytes (Fig.1).

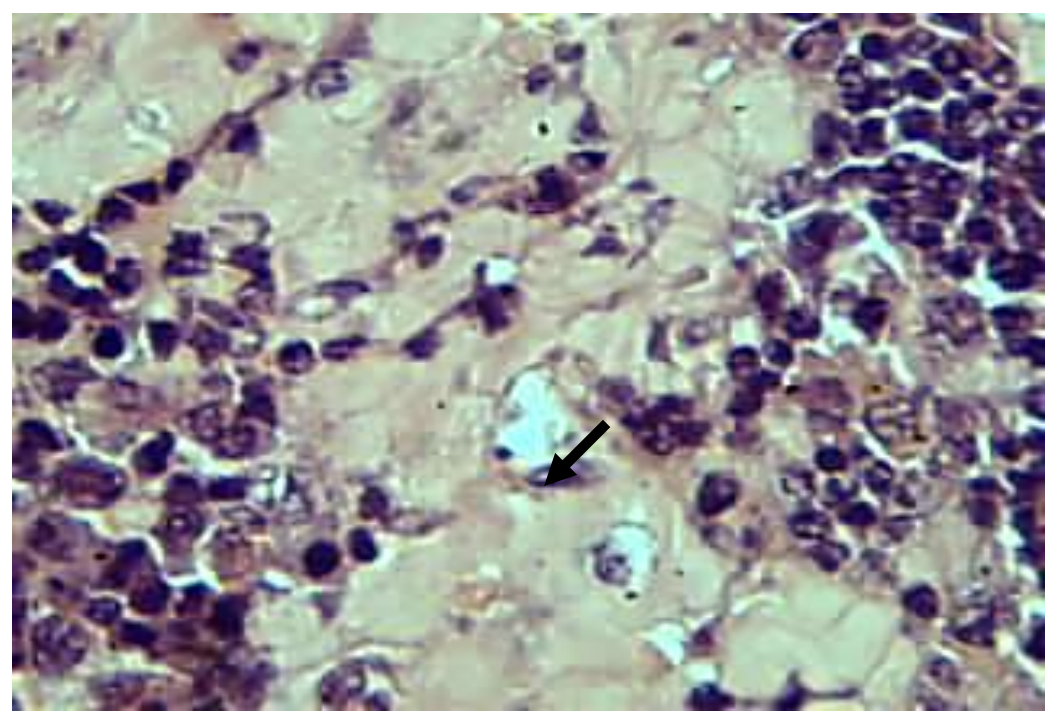

Histopathological effect in the spleen of ethanolic extract at the period of two weeks showed sever deposition of diffuse amyloid around the white bulb (H\&E X400). 


\section{Iraqi Journal of Veterinary Medicine Vol. 34, No. 1, 2010}

\section{Discussion}

This experiment was designed to evaluate the inhibitory effect of (ethanolic, cold aqueous and hot aqueous) extracts on AM-3 transplanted mice for (two weeks, three weeks and one month) periods of treatment.

The extractions of Sonchus oleraceus yield hot aqueous extract $(12.2 \%)$ which was the greater than $(8.7 \%)$ of ethanolic and cold aqueous $(8.1 \%)$ extracts. Differences between percentage of extracts may be due to some lost during processing of extraction depending on the type of preparation to each one. The extractions showed fine brown powder and sticky for both ethanolic and cold aqueous extract, but was dark brown sticky for hot aqueous extract. (7) mentioned that aqueous and ethanolic extracts had stronger antioxidant activities than any other extract from $S$. oleraceus.

Table (2) showed the presence of glycosides in all extracts of S. oleraceus, and presence of flavonoids and tannins only in ethanolic extract, but not found in the hot aqueous extracts and presence of tannins in cold aqueous extract, so absence of flavonoids and tannins or other components of the plant from hot aqueous extract may be due to the heating of extract, also the cold aqueous extract doesn't have flavonoids because this extract considered as water - soluble but not in alcohol- soluble, like as ethanolic extract, (9) proved that water - soluble plant extracts which are soluble in water; the active agents contained in such extracts include glycosides but not limited to flavonoid glycuronides and luteolin glycosides. The components may present in ethanolic and cold aqueous extracts but absent in hot aqueous extract (21).

The extracts have shown an effect by increasing the life span of animals (22).Al-Fatlawy (20) proved that the Withania somnifera dun roots caused a significance inhibitory effect on the experimentally induce adinocarcinoma in mice.

These results suggest that the extracts of Sonchus oleraceus have antitumour effect that needs more investigations. Cold and hot aqueous extracts manifest in treated mice sever necrosis of cancer mass particularly cold aqueous extract. This study proved that extracts of Sonchus oleraceus caused delay in the growth of transplanted tumor in mice and had the ability for preventing the growth.

The histopathological study showed, there are no significant lesion and no toxic abnormal changes in most organs of treated animal groups. At the period of two weeks treatment with ethanolic extract, the spleen referred to sever deposition of amyloid around the white bulb which leads to deplesion of the lymphocytes (Fig.1). The reason for amyloid association with disease is unclear, amyloid is an abnormal protein usually produced by cells in their bone marrow that can be deposited in any tissue or organ. Localized amyloidosis involves tumor-like nodules that localized amyloidosis may affect people with certain cancers. (23) mentioned there was deposition of amyloidosis (diffuse) in spleen at the dose $(0.1 \mathrm{mg} / \mathrm{kg} \mathrm{bw})$. Ethanolic extract in spite of the presence of amyloid in some organs, but exhibited the resistance of treated mice against mass of cancer cells by presence of thickness of interalveolar septa due to congestion of capillary blood vessel and mononuclear cells infiltration.

Treated mice with ethanolic extract showed infiltration of inflammatory cells especially after one month of treatment and this may be due to the defences of immune system in the body, in the lung mononuclear cells infiltration in the interstitial tissue as well as the blood vessels engorge. In tumour tissues, oxygen radicals are generated by cancer cells themselves, and infiltrating inflammatory cells such as neutrophils (24).

The three periods of treatment with hot aqueous extract showed mononuclear cells infiltration in the parenchyma of the kidney, and lung, and this may due to Tumour necrosis factor a (TNF) which considered is a potent, pleiotropic, proinflammatory cytokine that is produced by macrophages, neutrophils, fibroblasts, keratinocytes, NK, T-and B-cells and also by tumour cells. TNF binds to either of two receptors, TNF-R1 or TNF-R2, expressed on virtually all mammalian cell types. (25) said TNF was named because of its ability, when administered in pharmacologic doses, to cause necrosis of tumours in experimental models. TNF produced by 


\section{Iraqi Journal of Veterinary Medicine Vol. 34, No. 1, 2010}

the body mediates host responses in acute and chronic inflammatory conditions and aids in host protection from infection and malignancy.

In the group that treated with cold aqueous extract the period of one month noticed sever necrotic changes of cancer mass. Necrosis has already been defined as death of cells or tissues while the body as a whole still lives. It then acts as an irritant to surrounding living tissue and incites a cellular (leukocytic) inflammatory reaction around it (19). The necrosis is a characteristic histological feature in treatment which subsequently replaced by fibrous connective tissue as well as marked reduction in the tumour tissue. Microscopic study of histopathological changes was noticed sever congestion and necrosis of tissue cells in the spleen of animals treated with Green Tea Camellia sinensis according to (17).

The components of Sonchus oleraceus extracts may have activation of immune system beside anti tumour effect. This may explain the replacement tissue of tumour mass with large areas of necrosis and surrounding by inflammatory cells and mononuclear cells. During a wound healing response, inflammation occurs because immune cells accumulate at the site of tissue damage (26). The immune cells try to repair the damaged tissue by releasing various chemical signals (cytokines/chemokines) to create an environment that promotes cellular proliferation (growth). The immune cells maintain this enriched environment until the damaged tissue has been repaired or replaced with healthy tissue (18).

These results suggest that the extracts of Sonchus oleraceus have antitumour effect that needs more investigations.

\section{References}

1 - Sobol R E and Scanlon K J (2008). Cancer Gene Therapy. J Cit Reports. 15: 10-16.

2 - Ferguson P J Kurowska E Freeman D J Chambers A F and Koropatnick V (2004). A flavonoid fraction from cranberry extract inhibits proliferation of human breast cell lines. $\mathrm{J}$ Nut 134: 1529-1535

3 - Mukherjee A K Basu S Sarkar N and Ghosh A C (2001). Advances in Cancer Therapy with Plant Based Natural Products. Current Med Chem. 8: 1467-1486.

4 - Efferth T Kahl S Paulus K Adams M Rauh R Boechzelt H Hao X Kaina B and Bauer R(2008). Phytochemistry and Pharmacogenomics of Natural products derived from traditional Chinese medica with activity against tumor cells. Molecular Cancer Therapy. 7: 152-155.

5 - Howard L R Pandjaitan N Morelock T and Gil M I (2002). Antioxidant capacity and phenolic content of spinach as affected by genetics and growing season. J Agric Food Chem. 50: 5891-5896.

6 - Ma M Hong C L An S Q and Li B (2003). Seasonal, spatial, and interspecific variation in quercetin in apocynum venetum and poacynum hendersonii, Chinese traditional herbal teas. $\mathrm{J}$ Agric Food Chem. 51: 2390-2393.

7 - Yin J Kwon G J and Wang M H (2007). The antioxidant and cytotoxic activities of Sonchus oleraceus L. extracts. Nut Res Prac. 1: 189-194.

8 - Harborne J B (1984). Phytochemical methods: A guide to modern techniques of plant analysis. ( $2^{\text {nd }}$ ed.). Chapman and Hall, New York. Pp: 1-4.

9 - Timberlake C and Henry B (1988). Anthocyanins as Natural Food Colorants, Plant Flavonoids in Botanical Medicine II: Bioch Cellular Med properties. p. 107-121.

10 - Al-Muktar E S A (1994). Study the medical characters of some medical plants on 


\section{Iraqi Journal of Veterinary Medicine Vol. 34, No. 1, 2010}

laboratory mice. Ph.D. Thesis, College of Veterinary Medicine, University of Baghdad. Iraq. 11- Stahl E (1969). Thin-Layer-Chromatography, a Laboratory Hand book, (2 ${ }^{\text {nd }}$ ed.). Translated by Ashworth, M. R. F. Spring. Verag, Berlin, Heidelberg, New York.

12 - Smolensk S J Silinis H and Farans-worth N R (1972). Alkaloid screening lidia, 35: 31 34

13 - Harborne J B (1973). Phytochemical methods, a guide to modern technique of plant analysis. Halsted press. John Wiley and sons. New York. P. 278-281.

14 - Dixon W J (1980). Efficient analysis of experimental observations. Ann Res Pharmacol Toxicol 20: 441-462.

15 - Al-Shamery A M H (2003). The study of Newcastle disease virus effect in the treatment of transplanted tumor in mice. M.Sc. Thesis. College of veterinary medicine, University of Baghdad, Iraq.

16- Corbett T H Robert B J Leopold W R Pockham J C Wikoft L J Gioswold D P and Schobel F M (1984) :Introduction and chemotherapeutic response of two transplantable ductal adnocarcinomas of the pancrease in C57BL16mice.Canc. Res. 44: 717-726.

17 - Umran M A (2008). Influence of Polyphenols Extracts of Green Tea Camellia sinensis on The Normal and Cancer Cells Lines In Vivo and In Vitro. Ph.D. Thesis. College of Science. University of Baghdad, Iraq.

18- Coussens L and Werb Z (2002). Inflammation and Cancer. Nature. 420: 860-867.

19 - Smith J H (1972). Veterinary Pathology. 4th ed. Lea and Febiger, U.S.A. p. 17-24.

20- AL- Fatlawy A H J (2007). Study the in vitro and in vivo effect of ALcoholic extracts of Withania somnifera dun roots on cancer cell line and experimentally induced mammary adenocarcinoma in mice. M.Sc Thesis Coll Veter Med. Baghdad University Iraq..

21 - Boonyaprapatsorn N and Chokchaijaroenporn A (2000). Medicinal Plant. Medicinal Plant Data Center, Faculty of Pharmaceutical Sciences, Mahidol University, Bangkok.

22 - Hullatti K K Murthy U D and Shrinath B R (2006). In vitro and In vivo inhibitory effects of Piper longum fruit extracts on mouse Ehrlich ascites carcinoma. Pharmac Magaz. 9731296.

23- AL-Taae E H Y (2007). Study of Pathological, Immunological and Cytogenetics Effect of Urtica dioica on Cancer Cells Growth in vitro and Treatment of Transplanted Tumor in White Mice in vivo. PhD Thesis College of Vet Medicine University of Baghdad, Iraq.

24- Oberley T D and Oberley L W (1997). Antioxidant enzyme levels in cancer. Histol Histopathol 12: 525-535.

25 - Witte M Shealy D J Nakada M T and Anderson G M (2003). Cancer Cytokines in the Genesis and Treatment of Cancer. Oncology Res. 1: 455-460.

26 - Rakoff-Nahoum S (2006). Why Cancer and Inflammation? Yale J Biolo Med. 79: 123130. 